\title{
Interactions of High Temperature and Exposure Time Influence Nitrification in a Pine Bark Medium
}

\author{
Ronald F. Walden ${ }^{1}$ \\ Hampton Roads Agricultural Research and Extension Center, Virginia \\ Polytechnic Institute and State University, Virginia Beach, VA 23455-3363 \\ Robert D. Wright ${ }^{2}$ \\ Department of Horticulture, Virginia Polytechnic Institute and State University, \\ Blacksburg, VA 24061-0327
}

Additional index words. container-grown, fertilization, nitrogen, soilless media

\begin{abstract}
Pine bark-filled containers periodically fertilized with $\mathrm{NH}_{4}-\mathrm{N}$ were heated from $21 \mathrm{C}$ to $28,34,40,46$, or $52 \mathrm{C}$ for daily exposures of $1,2,4,6$, or 24 hours over 20 days. Concentrations of $\mathrm{NH}_{4}-\mathrm{N}$ and $\mathrm{NO}_{3}-\mathrm{N}$ in medium solution extracts were determined every 5 days. Medium solution $\mathrm{NH}_{4}-\mathrm{N}$ concentration was higher at constant ( 24 hours) exposure to $40 \mathrm{C}$ than at lower temperatures or exposure times. There was a similar increase in $\mathrm{NH}_{4}-\mathrm{N}$ concentration for a 2 -hour $\cdot \mathrm{day}^{-1}$ exposure to $46 \mathrm{C}$, with further increases in $\mathrm{NH}_{4}-\mathrm{N}$ for longer exposure times. By day $10, \mathrm{NH}_{4}-\mathrm{N}$ concentration was highest after 1 hour $\cdot \mathrm{day}^{-1}$ exposure to $52 \mathrm{C}$. Decreases in medium solution $\mathrm{NO}_{3}-\mathrm{N}$ concentration generally coincided with the increases in $\mathrm{NH}_{4}-\mathrm{N}$. These results indicate that container medium thermal periods, similar to those observed in nurseries of the southern United States, may inhibit nitrification, thereby influencing $\mathrm{NH}_{4}-\mathrm{N}: \mathrm{NO}_{3}-\mathrm{N}$ ratios in the medium solution of plants fertilized with predominantly ammoniacal $\mathrm{N}$ sources.
\end{abstract}

Growth and quality of container-grown plants in southern U.S. nurseries can be limited by the supraoptimal medium temperatures that result from heat gain due to solar radiation on the sidewalls of dark containers (Ingram, 1981; Keever and Cobb, 1984; Laiche, 1985). Daily medium temperatures can be $>40 \mathrm{C}$ for $\leq 6 \mathrm{~h}$ and $50 \mathrm{C}$ for $\leq 2 \mathrm{~h}$ (Ingram, 1981; Martin and Ingram, 1988). Temperatures this high may inhibit nitrification (Beck, 1983), potentially increasing the $\mathrm{NH}_{4}-\mathrm{N}: \mathrm{NO}_{3}-\mathrm{N}$ ratio in the medium solution when plants are fertilized with ammoniacal N. Heat-induced $\mathrm{NH}_{4}$ toxicity may be one factor contributing to summer heat stress of container-grown plants (Walden et al., 1989).

In a pine bark medium at constant temperature, 20 or $30 \mathrm{C}$ promoted rapid nitrification, but nitrification was inhibited at $40 \mathrm{C}$ (Niemiera and Wright, 1987). This inhibition increased the $\mathrm{NH}_{4}-\mathrm{N}$ concentration relative to that of

Received for publication 7 Sept. 1994. Accepted for publication 8 Feb. 1995. Research was funded in part by the Virginia Nurseryman's Association. This paper is a portion of a dissertation submitted by Ronald F. Walden in partial fulfillment of the requirements for a $\mathrm{PhD}$ in horticulture. The technical assistance of Galina Epelman is gratefully acknowledged. The cost of publishing this paper was defrayed in part by the payment of page charges. Under postal regulations, this paper therefore must be hereby marked advertisement solely to indicate this fact.

${ }^{1}$ Assistant Professor.

${ }^{2}$ Professor.
$\mathrm{NO}_{3}-\mathrm{N}$ in the medium solution extracts. The $\mathrm{NH}_{4}-\mathrm{N}$ concentrations in leachates from a container nursery was higher during August than the cooler month of September (Walden et al., 1989). This information suggests that the container medium may reach temperatures sufficiently high for an adequate period to inhibit nitrification. Our objective was to determine the temperatures and the daily exposure durations that inhibit nitrification in a pine bark medium. Knowledge of this interaction would help producers of container-grown plants adjust cultural practices for plants that may be sensitive to elevated $\mathrm{NH}_{4}-\mathrm{N}$ levels in the medium solution.

\section{Materials and Methods}

Preincubation procedure. One-liter polyethylene containers were filled with a milled pine bark medium amended with $6 \mathrm{~kg}$ dolomitic limestone $/ \mathrm{m}^{3}$. To stimulate nitrification, each container received a twice weekly irrigation with $200 \mathrm{ml}$ of a solution containing 200 $\mathrm{mg} \mathrm{N} /$ liter as $\left(\mathrm{NH}_{4}\right)_{2} \mathrm{SO}_{4}$. The containers were held for a 90-day preincubation period in a room where the temperature varied from 21 to $28 \mathrm{C}$. At the end of this period, the establishment of a nitrifier population was verified by the appearance of $\mathrm{NO}_{3}^{-}$in the medium solution extracted by the pour-through procedure (Wright, 1986). Distilled water $(75 \mathrm{ml})$ was applied to the container medium surface $2 \mathrm{~h}$ after irrigation. The resultant leachate was collected and analyzed for $\mathrm{NO}_{3}-\mathrm{N}$ and $\mathrm{pH}$ using ion selective electrodes. The medium solution $\mathrm{pH}( \pm \mathrm{SE})$ of a sampling from 10 containers was $5.9 \pm 0.2$. Although the optimum
$\mathrm{pH}$ range for nitrification is thought to be 7 to 8 (Focht and Verstraete, 1977), nitrification readily occurs in a pine bark medium between pH 5 and 6 (Niemiera and Wright, 1986).

Incubation procedure. On the morning following the preincubation period, 24 containers were placed in each of five temperaturecontrolled chambers maintained at 28, 34, 40, 46 , or $52 \pm 0.3 \mathrm{C}$. The surface of each container was covered by a plastic disk to retard moisture loss from the medium. The containers in each chamber were gradually heated to their respective chamber temperature over $\approx 4 \mathrm{~h}$. Then five containers were selected randomly for removal from each chamber at intervals of $1,2,4$, and $6 \mathrm{~h}$ after the medium attained the chamber temperature. Medium temperatures were monitored with a CR10 data acquisition system (Campbell Scientific, Logan, Utah) by soldered copper constantan thermocouples placed in the center of the medium in the five containers that were the last to be removed from a chamber.

Following removal from a chamber, the containers were held in a room with a $28 \mathrm{C}$ day/ $22 \mathrm{C}$ night cycle and were allowed to equilibrate to room temperature. This sequence was repeated every $24 \mathrm{~h}$ using the same five containers, randomly placed in a chamber, for each temperature-exposure time combination. Four containers remained in each chamber for continuous $\left(24 \mathrm{~h} \cdot \mathrm{day}^{-1}\right)$ exposure to the chamber temperature.

The medium attained the chamber temperature within $4 \mathrm{~h}$ of placing into a chamber in all five chambers, with little variation in temperature during the exposure time (Fig. 1). Following removal from a chamber, the containers equilibrated to room temperature in $\approx 5$ h. The gradual heating and cooling of the medium each day was intended to simulate temperature patterns observed in southern U.S. nurseries during summer months (Ingram, 1981; Martin and Ingram, 1988).

Before their initial placement into the chambers, containers were irrigated with $200 \mathrm{ml}$ of a nutrient solution that contained (in mg.liter ${ }^{-1}$ ) $200 \mathrm{~N}^{-1} 0 \mathrm{P}-25 \mathrm{~K}$ as $\left(\mathrm{NH}_{4}\right)_{2} \mathrm{SO}_{4}, \mathrm{H}_{3} \mathrm{PO}_{4}$, and $\mathrm{KCl}$, respectively. After a 2-h drainage, an initial weight was recorded for each container. All containers were brought back to this initial weight by adding distilled water at the start of each 24 -h period; this procedure was intended to keep medium moisture levels above that which might inhibit nitrification.

Every 5 days, the medium solution of each container was extracted by the pour-through procedure $2 \mathrm{~h}$ after the containers had been returned to their initial weight. Then containers were fertilized with $200 \mathrm{ml}$ of the nutrient solution, drained for $1 \mathrm{~h}$, and returned to the temperature-controlled chambers. This procedure was followed for 20 days, resulting in four extraction dates during the experiment. There were five replicate extracts for each temperature-exposure time combination, with the exception of the 24-h exposure, which had only four replications due to space limitations in the chambers. Medium solution extracts were analyzed for $\mathrm{NH}_{4}-\mathrm{N}$ and $\mathrm{NO}_{3}-\mathrm{N}$ using ion selective electrodes. 


\section{Results and Discussion}

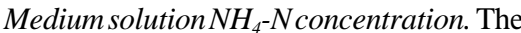
effects of temperature and daily exposure duration on the $\mathrm{NH}_{4}-\mathrm{N}$ concentration in medium solution extracts were similar for all four extraction dates (Fig. 2). Medium solution concentrations of $\mathrm{NH}_{4}-\mathrm{N}$ were low at 28 and $34 \mathrm{C}$ for all daily exposure times and at $40 \mathrm{C}$ for daily exposures of $\leq 6 \mathrm{~h}$. The low $\mathrm{NH}_{4}-\mathrm{N}$ concentrations in the medium solution, particularly after 15 and 20 days, indicate that, for these treatments, the availability of substrate $\left(\mathrm{NH}_{4}-\mathrm{N}\right)$ did not exceed the oxidative capacity of the nitrifiers. Nitrification rates decline in mineral soil above the optimum of 26C (Beck, 1983). In a pine bark medium supplied with $\mathrm{NH}_{4}-\mathrm{N}$, $\mathrm{NO}_{3}$ accumulation rates were significantly lower at $40 \mathrm{C}$ than at $30 \mathrm{C}$ (Niemiera and Wright, 1987). Presumably in our study, the container medium exposed to $40 \mathrm{C}$ for $\leq 6 \mathrm{~h} \cdot \mathrm{day}^{-1}$ experienced lower, more optimum temperatures for sufficient periods during the five days between extractions to nitrify amounts of applied $\mathrm{NH}_{4}-\mathrm{N}$ equivalent to that nitrified at 28 or 34C. Alternatively, fluctuating medium temperatures may have stimulated nitrification as Campbell et al. (1973) reported in mineral soil.

On all extraction dates, the $\mathrm{NH}_{4}-\mathrm{N}$ concentration in medium extracts from the $40 \mathrm{C}$ treatments was higher for the 24 -h.day ${ }^{-1}$ exposure than for shorter exposure times (Fig. 2). This apparent nitrification inhibition (higher medium extract $\mathrm{NH}_{4}-\mathrm{N}$ ) caused by constant exposure to $40 \mathrm{C}$ agrees with Niemiera and Wright's (1987) results. On most days, there was a similar increase in $\mathrm{NH}_{4}-\mathrm{N}$ for the 2$\mathrm{h} \cdot \mathrm{day}^{-1}$ exposure to $46 \mathrm{C}$, with greater increases for longer exposures to this temperature. The further nitrification inhibition by temperatures $>40 \mathrm{C}$ indicates that nitrification was not completely inhibited at $40 \mathrm{C}$, even after 20 days of constant exposure to this temperature.

The maximum level of $\mathrm{NH}_{4}-\mathrm{N}$ concentration in medium solution extracts was found generally after $24 \mathrm{~h} \cdot \mathrm{day}^{-1}$ exposure to $46 \mathrm{C}$ or after $1 \mathrm{~h} \cdot \mathrm{day}^{-1}$ exposure to $52 \mathrm{C}$, with no significant increases for longer exposures to 52C. These results indicate that a short-term $(1 \mathrm{~h})$ daily exposure of the container medium to 52C completely inhibited nitrification, but the effect at $46 \mathrm{C}$ varied with the exposure duration. Beck (1983) found that the activity of nitrifying organisms ceased in mineral soil with incubation at 50C. Ingram (1985) found similar temperature $\times$ exposure duration interactions on the root cell membrane thermostability of Pittosporum tobira Thunb. Using an electrolyte leakage model to describe these interactions, direct membrane injury was predicted for a $30-\mathrm{min}$ exposure to $52.2 \mathrm{C}$ or a 5-h exposure to $46.3 \mathrm{C}$. In our study, 46C seemed to be a critical temperature for nitrification in a pine bark medium because $\mathrm{NH}_{4}-\mathrm{N}$ increased at this temperature in direct proportion to the exposure duration.

Medium solution $\mathrm{NO}_{3}-\mathrm{N}$ concentration. Medium solution $\mathrm{NO}_{3}-\mathrm{N}$ concentrations decreased over time for all temperatureexposure time combinations (Fig. 2). The largest decreases in $\mathrm{NO}_{3}-\mathrm{N}$ concentration generally corresponded to temperature-related increases in $\mathrm{NH}_{4}-\mathrm{N}$ concentration, consistent with a nitrification inhibition. This relationship was strongly evident by day 15 . At $46 \mathrm{C}$, the medium solution $\mathrm{NO}_{3}-\mathrm{N}$ concentration decreased for exposures $>2 \mathrm{~h} \cdot \mathrm{day}^{-1}$ compared to that at lower temperature or exposure time. The lowest $\mathrm{NO}_{3}-\mathrm{N}$ concentrations were associated with $24 \mathrm{~h} \cdot \mathrm{day}^{-1}$ exposure to $46 \mathrm{C}$ or any exposure of the medium to $52 \mathrm{C}$. Medium solution $\mathrm{NO}_{3}-\mathrm{N}$ and $\mathrm{NH}_{4}-\mathrm{N}$ concentrations were negatively correlated on day 15 (Fig. 3). By day 20, $1 \mathrm{~h} \cdot \mathrm{day}^{-1}$ exposure to $52 \mathrm{C}$ resulted in a medium solution $\mathrm{NH}_{4}-\mathrm{N}: \mathrm{NO}_{3}-\mathrm{N}$ ratio that was $\approx 70$ times higher than that which resulted from constant exposure to $28 \mathrm{C}$ (Fig. 2).

Our results indicate that patterns of container medium temperature in southern U.S. nurseries in midsummer often are capable of inhibiting nitrification, thereby influencing the $\mathrm{NH}_{4}-\mathrm{N}: \mathrm{NO}_{3}-\mathrm{N}$ ratio in the medium solution of plants fertilized with ammoniacal N. Medium temperature and exposure duration must

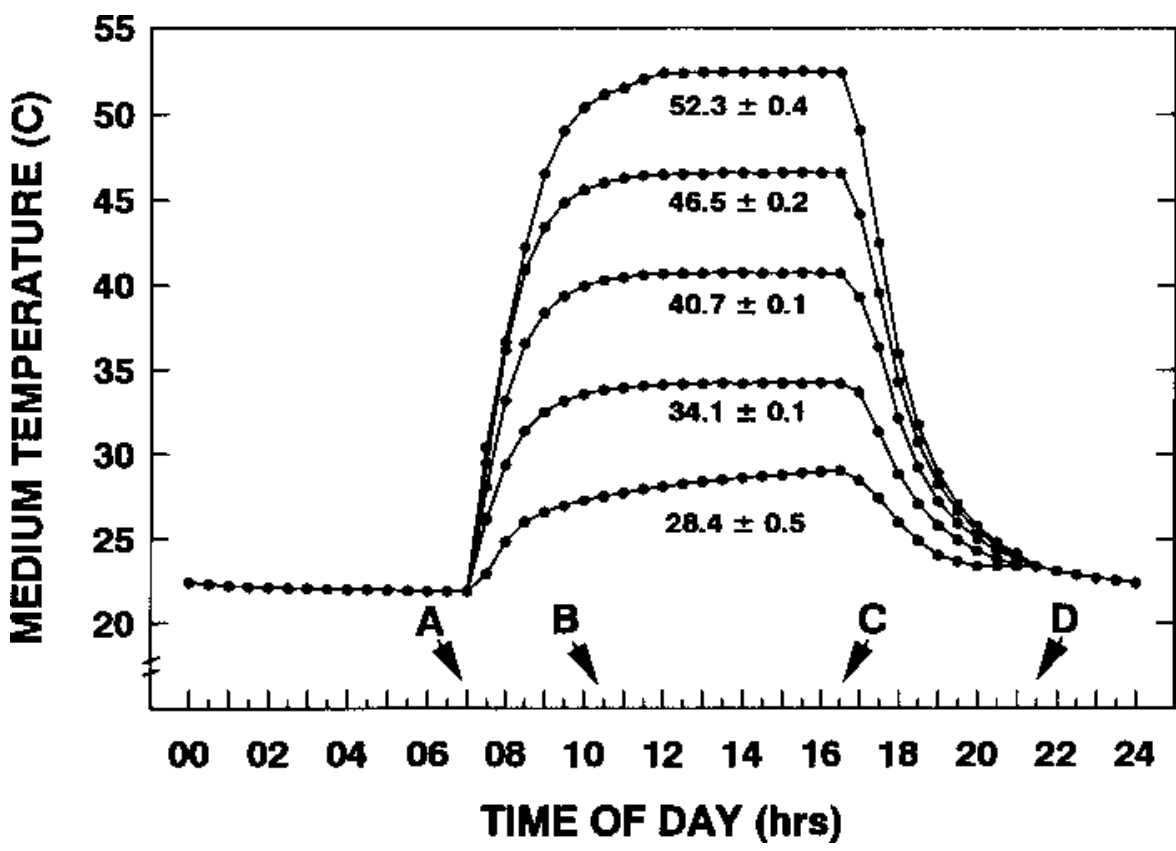

Fig. 1. Diurnal temperatures of container medium exposed to five chamber temperatures. Each point between placement of the containers into a chamber at (A) $0700 \mathrm{HR}$ and equilibration to room temperature at (D) $2100 \mathrm{HR}$ represents the mean of five containers. Mean medium temperatures $\pm \mathrm{sE}$ are shown for each chamber during a 6-h exposure beginning at (B) $1030 \mathrm{HR}$, when the medium reached the chamber temperature, and ending at (C) $1630 \mathrm{HR}$, when the containers were removed from the chambers.

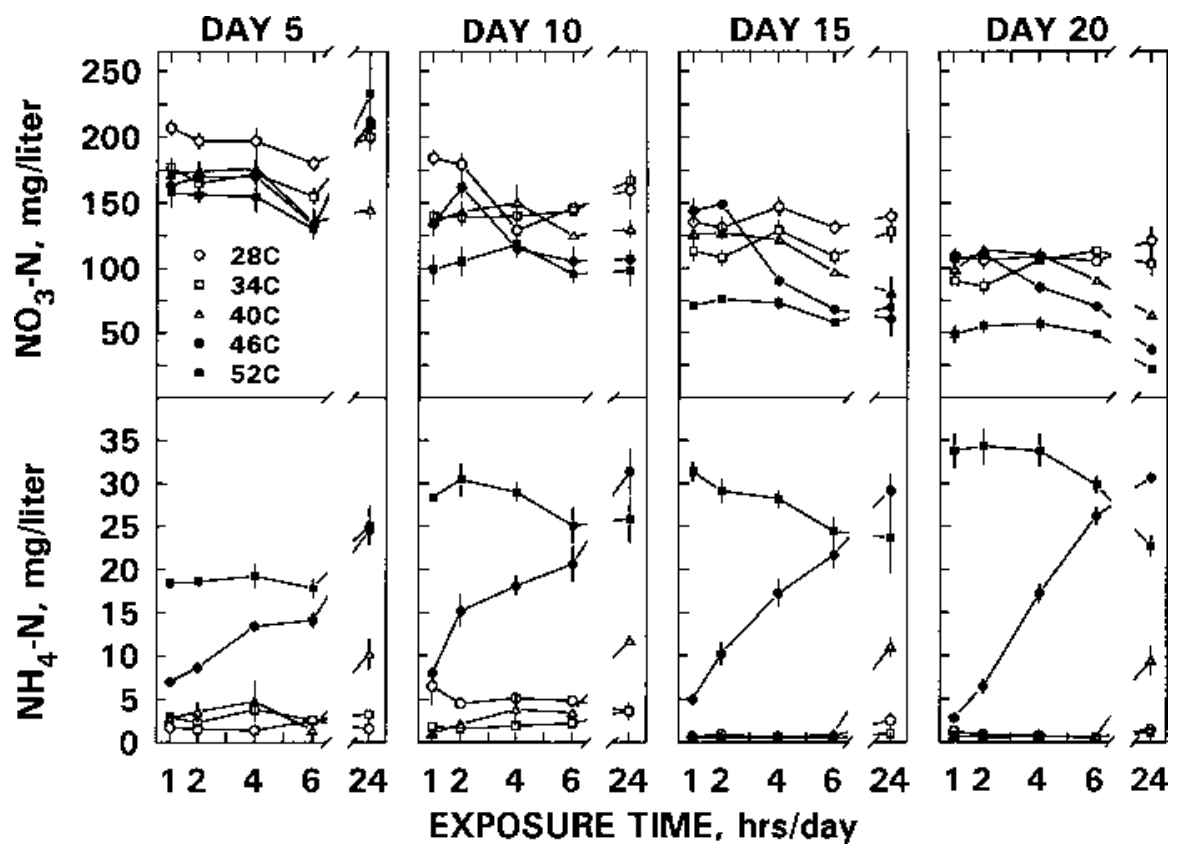

Fig. 2. Influence of medium temperature and daily exposure duration on medium extract $\mathrm{NH}_{4}-\mathrm{N}_{\text {and }} \mathrm{NO}_{3}$ $\mathrm{N}$ concentrations over 20 days. Extracts on each date were obtained 5 days after fertilization. If bars are not indicated, the SE of $\mathrm{NH}_{4}-\mathrm{N}$ and $\mathrm{NO}_{3}-\mathrm{N}$ is $<1.0$ and $<3.0$ mg.liter ${ }^{-1}$, respectively. 
be considered in defining conditions that are critical for nitrification.

In this experiment, $>6 \mathrm{~h} \cdot \mathrm{day}^{-1}$ exposure to 40C was required to inhibit nitrification in pine bark. Previous work has shown that the influence of $6 \mathrm{~h} \cdot \mathrm{day}^{-1}$ exposure to $40 \mathrm{C}$ on nitrification in pine bark can depend on the limestone amendment level (Walden, 1993), which encourages nitrification (Niemiera and Wright, 1986). A medium temperature of 46C had the greatest interaction with exposure time on nitrification, with little inhibition for a short-term exposure $\left(1 \mathrm{~h} \cdot \mathrm{day}^{-1}\right)$ and increasing inhibition for longer daily exposure times. Because nursery containers generally are at their maximum temperature for $<1 \mathrm{~h} \cdot \mathrm{day}^{-1}$ (Ingram, 1981; Young and Hammet, 1980), there likely will be no heat-induced elevation of medium solution $\mathrm{NH}_{4}-\mathrm{N}$ concentration if maximum container temperatures do not exceed $46 \mathrm{C}$ when ammoniacal $\mathrm{N}$ sources are used. Furthermore, when the maximum medium temperature in nursery containers does not exceed 46C, medium temperature will not exceed 40C for $>6 \mathrm{~h}$ (Ingram, 1981; Martin and Ingram, 1992; Walden, 1993).

Southern U.S. nurseries producing plants that might be sensitive to elevated $\mathrm{NH}_{4}-\mathrm{N}$ : $\mathrm{NO}_{3}-\mathrm{N}$ ratios in the medium solution should adopt cultural practices that prevent maximum medium temperatures from exceeding 46C. Alternatively, using fertilizers containing $\leq 50 \% \mathrm{NH}_{4}-\mathrm{N}$ in midsummer is advised. Additionally, when choosing a target maximum container medium temperature, it would be prudent to consider the many documented cases of negative growth responses of woody plants to root-zone temperatures near 40C (Harrison et al., 1988; Johnson and Ingram, 1984; Martin et al., 1989; Ruter and Ingram, 1990; Walden, 1993; Yeager et al., 1991).

\section{Literature Cited}

Beck, T. 1983. Mineralization of soil nitrogen in laboratory incubation experiments. Z Pflanzenernähr. Bodenk. 120:71-78.

Campbell,C.A., V.O. Biederbeck, and F.G. Warder. 1973. Influence of simulated fall and spring conditions on the soil system: III. Effect of method of simulating spring temperatures on ammonification, nitrification and microbial populations. Soil Sci. Soc. Amer. Proc. 37:382386.

Focht, D.D. and W. Verstraete. 1977. Biochemical ecology of nitrification and denitrification. Adv. Microbiol. Ecol. 1:135-214.

Harrison, R.H., T.H. Yeager, and D.L. Ingram. 1988. Growth response and nutrient uptake by Photinia $\times$ fraseri at supraoptimal root-zone temperatures. Proc. Southern Nurserymen's Assn. Res. Conf. 33:68-70.

Ingram, D.L. 1981. Characterization of temperature fluctuations and woody plant growth in white poly bags and conventional black containers. HortScience 16:762-763.

Ingram, D.L. 1985. Modeling high temperature and exposure time interactions on Pittosporum tobira root cell membrane thermostability. J. Amer. Soc. Hort. Sci. 110:470-473.

Johnson, C.R. and D.L. Ingram. 1984. Pittosporum tobira response to container medium temperature. HortScience 19:524-525.

Keever, G.J. and G.S. Cobb. 1984. Container and production bed mulch effects on media temperatures and growth of 'Hershey's Red' azalea. HortScience 19:439-441.

Laiche, A.J., Jr. 1985. Effect of time of spacing on the growth of container-grown Ilex cornuta 'Dwarf Burford', Lindl. and Paxt., and Pittosporum tobira, Thumb. J. Environ. Hort. 3:22-24.

Martin, C.A. and D.L. Ingram. 1988. Temperature dynamics in black poly containers. Proc. Southern Nurseryman's Assn. Res. Conf. 33:71-74.

Martin, C.A. and D.L. Ingram. 1992. Simulation modeling of temperatures in root container media. J. Amer. Soc. Hort. Sci. 117:571-577.

Martin, C.A., D.L. Ingram, and T.A. Nell. 1989. Supraoptimal root-zone temperature alters growth and photosynthesis of holly and elm. J. Arbor. 15:272-276.

Niemiera, A.X. and R.D. Wright. 1986. Effect of liming rate on nitrification in a pine bark me- dium. J. Amer. Soc. Hort. Sci. 111:713-715.

Niemiera, A.X. and R.D. Wright. 1987. Influence of temperature on nitrification in a pine bark medium. HortScience 22:615-616.

Ruter, J.M. and D.L. Ingram. 1990. ${ }^{14}$ Carbon-labelled photosynthate partitioning in Ilex crenata 'Rotundifolia' as supraoptimal root-zone temperatures. J. Amer. Soc. Hort. Sci. 115:10081013.

Walden, R.F. 1993. Influences of supraoptimal rootzone temperature on the medium solution and growth of woody nursery crops. PhD Diss., Virginia Polytechnic Institute and State Univ., Blacksburg.

Walden, R.F., R.D. Wright, and A.X. Niemiera. 1989. Heat induced ammonia toxicity of container-grown nursery crops. Proc. Southern Nurserymen's Assn. Res. Conf. 34:80-83.

Wright, R.D. 1986. The pour-through nutrient extraction procedure. HortScience 21:227-229.

Yeager, T.H., R.H. Harrison, and D.L. Ingram. 1991. 'Rotundifolia' holly growth and nitrogen accumulation influenced by supraoptimal rootzone temperatures. HortScience 26:1387-1388.

Young, K. and K.R.W. Hammet. 1980. Temperature patterns in exposed black polyethylene plant containers. Agr. Meteorol. 21:165-172.

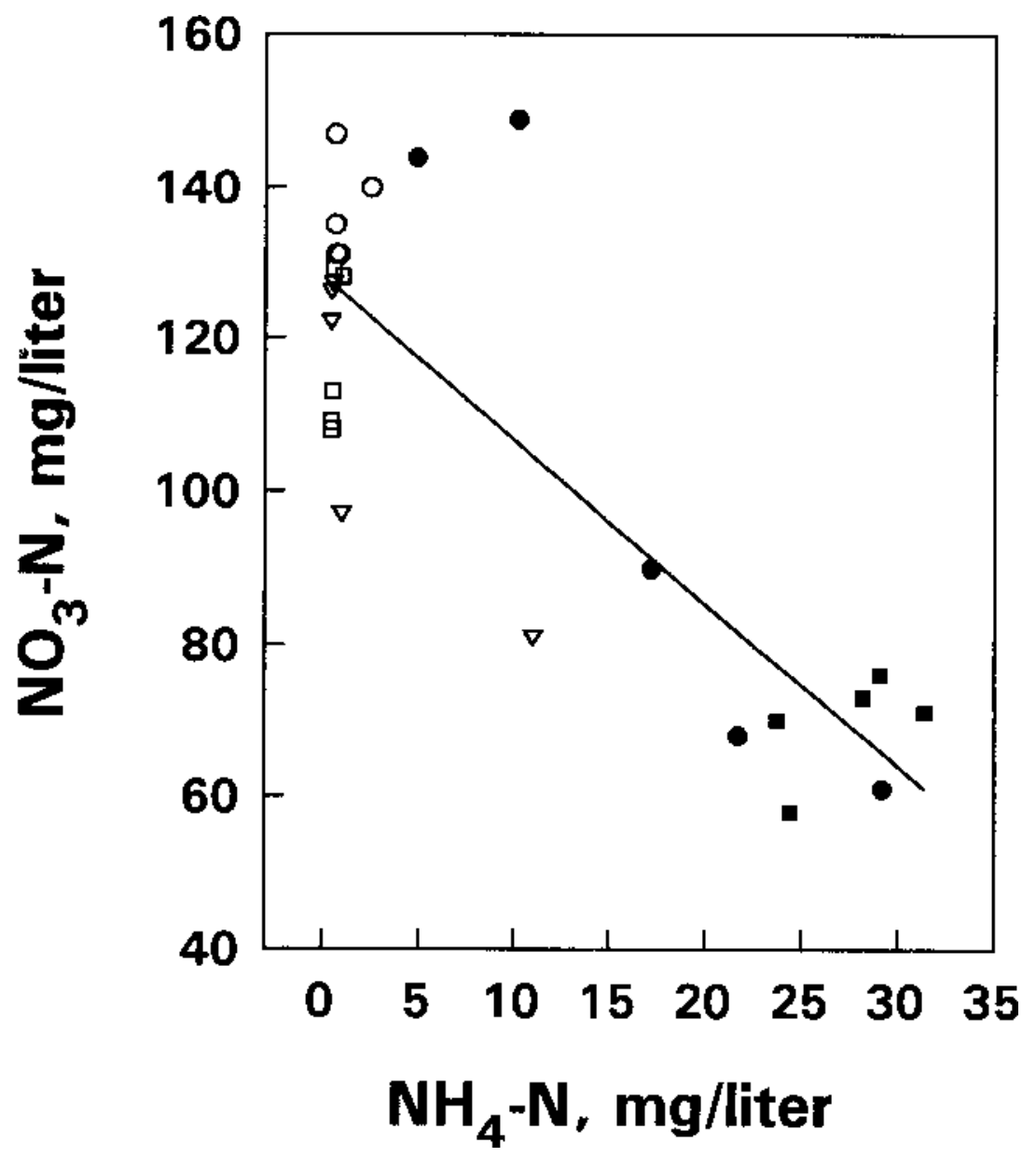

Fig. 3. The relationship between $\mathrm{NO}_{3}-\mathrm{N}$ and $\mathrm{NH}_{4}-\mathrm{N}$ concentrations in medium solution extracts on day 15 for all temperature-exposure time combinations. $\mathrm{y}=128-2.13 \mathrm{x} ; r=-0.84$. Symbols denoting temperature treatments are the same as for Fig. 2. 